\title{
Three Types of Tightrope Dance in the Comeback Process
}

\author{
Preliminary Findings from a Longitudinal Study of Young People at \\ the Margins of Upper Secondary School in Norway
}

\author{
Mette Bunting*, Torill Aagot Halvorsen, and Geir H Moshuus \\ University College of Southeast Norway \\ Kjølnes ring 56, 3900 Porsgrunn, Norway
}

Received: 31.01.2017; Accepted: 10.04.2017; Published: 31.08.2017

\begin{abstract}
Fewer than half of the young people attending vocational institutions in Norway complete their education within the allotted five years. Indeed, many of these students have non-linear paths to completion. However, it is not changes in the dropout rate that make this different from earlier generations but the expansion of formal education and the rise of the knowledge society and individualisation. The term 'tightrope biographies' is used here to encapsulate why individualisation cannot be thought of in terms of choice, because today's youth are often held accountable for their educational progression rather than this progression being viewed as dependent on institutional mechanisms. The present study characterises young people as tightrope dancers in their interactions with vocational schools. Selected data collected from ethnographic interviews during the ongoing longitudinal project Youth, Completion and Dropout in Telemark are used here to capture the voices of young people. These data focus on the non-linear educational careers of these youth when they re-enter schools and explore the stories they tell about dropping out and re-entering. These stories suggest that, to succeed, students need customised support throughout the process from school to the workplace and that many depend on this support. The study identifies three different ways of understanding these students as tightrope dancers trying to get back on track, characterising them as The Steady, The Shaky and The Shivering.
\end{abstract}

Keywords: VET, Vocational Education and Training, School Leavers, Tightrope Biographies, Knowledge Society, Continuing Vocational Education and Training, Re-entry Students, Pushout, Youth Research

\footnotetext{
*Corresponding authors: mette.bunting@usn.no, torill.a.halvorsen@usn.no, geir.moshuus@usn.no
}

ISSN: $2197-8646$

http://www.ijrvet.net 


\section{Introduction}

In this article, we look at young people's non-linear re-entry to vocational education. After dropping out of school, they received help over time from the welfare system prior to re-entry. Their stories about dropping out and re-entry to vocational education seem to describe the experience in three different ways, which are characterised here as 'tightrope biographies' as they find their individual trajectories into adult life.

The term 'tightrope biographies' originates in Beck's individualisation theory of social change (Beck \& Beck-Gernsheim, 1996, p. 25) and was subsequently referred to by Woodman and Wyn in their reappraisal of Beck's thesis (2015, pp. 46-47). Its use in the present context enables us to see beyond particular stories to how shared structural challenges shape the individual choices made by young people finding their way back to vocational education. Interpreted as biographies, these back to school stories reveal how the individual's choice is structurally mediated, limiting their possible trajectories of completion and reflecting unequal opportunities beyond individual decision making.

Our starting point is an ongoing longitudinal qualitative research project 1 , following about 70 young over a period of ten years. This article focus on those youths that dropped out and then re-entered vocational education. All of the participants are of school age (16-21 years), and the data used here were collected in the first three years of the study. Looking at their non-linear schooling, the study asks what are their stories of dropping out and re-entry?

Following analytical scrutiny, the preliminary findings were organised into individual stories representing one of the three tightrope biographies: those who seem, at this point, to be doing well ("The Steady"); those whose stories suggest that they may not be doing so well ("The Shaky"); and those whose stories seem likely to end in another dropout ("The Shivering"). The findings to date suggest that of the many young people who return to school intending to complete, some will need extensive support if they are to achieve this. To improve their situation, that support must compensate for inherent inequalities.

\section{Young people, education and biographies}

Young people grow up in a very different world from the one their parents knew as young people (Guest, 2016). Across the globe, workers with an upper secondary education are known to earn higher salaries than those with a lower level of education, and in every country, unemployment decreases as educational attainment increases (OECD, cited in Woodman \& Wyn, 2015, p. 20). Globally, from being a privilege for the few, education has progressed to become an accessible option for all (UIS (The UNESCO Institute for Statistics), cited in Woodman \& Wyn, 2015). The expansion of formal education is characterised by the higher rate of entry to higher education, transforming

${ }^{1}$ Youth, Completion and Dropout in Telemark is financed by Telemark University College (2013-2015) and the University College of Southeast Norway (2016-2023), and is receiving funding over three years (2015-18) from the Norwegian Labour and Welfare Administration (https://www.nav.no/fou). 
our world into 'a schooled society' and dramatically altering human life (Baker, 2014). The rise of the knowledge society creates a demand for highly educated employees, and Baker maintains that education characterises, creates and defines society rather than the other way around (Baker, 2014). Baker characterises this education revolution as a cultural phenomenon: 'a new model of society holds that secondary education has become necessary to be a modern person' (Baker, 2014, p. 228). This context also creates the concept of dropout as a global phenomenon that threatens to have a decisive impact on the lives of young people.

The current study is situated in Norway, where students who are successful at school are likely to have grown up with highly educated, high-income parents (Falch \& Nyhus, 2011; Markussen, 2014; Markussen, Frøseth, Lødding, \& Sandberg, 2008). Although the Norwegian government applied the standard of a common school for all as early as 1920, socioeconomic background determines upper secondary school students' success at school in terms of engagement and grades, which in turn influence performance (Markussen, Frøseth, \& Sandberg, 2011). The Norwegian educational system is mostly governmentally financed for compulsory schooling from first to tenth grade, as well as for upper secondary education. While all are entitled to upper secondary education, this is not obligatory (Markussen, Frøseth, Sandberg, Lødding, \& Borgen, 2011).

The Norwegian upper secondary school system has seen many reforms, the most recent of which (in 1994) applied to vocational education. For young people who had finished lower secondary school and were entering upper secondary education, this reform gave them the legal right to at least one of their three educational choices. This reform also introduced the ' $2+2$ ' model, comprising two years in school and two years of apprenticeship (Hiim, 2017; Markussen, Frøseth, \& Sandberg, 2011). This involves cooperation between the educational system (providing schooling) and the employment sector (providing apprenticeships). Before entering their placements, students must pass all of their exams and complete their courses. Students attending a vocational study programme can also switch from the apprenticeship system to complete a general academic course that extends their schooling to a third year; upon completion, students can access higher education. Vocational students can also switch from one vocational programme to another; students who fail to get an apprenticeship, drop out or decide that their educational choice was a mistake still have the legal right to join another strand, within a period of five years following completion of lower secondary school (Markussen, Frøseth, \& Sandberg, 2011).

According to national statistics (Statistisk Sentralbyrå, 2016), fewer students complete the vocational $(58 \%)$ than the general strand $(73 \%)$. A quarter of students attending vocational strands drop out within the five year period; many decide to take the third year leading to higher education, and about $41 \%$ complete their vocational training (Gjennomføringsbarometeret, 2015). Overall, about half of the total student group commences vocational training. However, completion statistics indicate that only $16 \%$ of the cohort have completed this training after five years (Reegård \& Rogstad, 2016).

Most of the students who drop out of the vocational strand do so after their two years at school. According to Høst (2008) (cited in Markussen, Frøseth, \& Sandberg, 2011), the percentage of students nationally applying for apprenticeships fluctuates from $65 \%$ 
to $80 \%$, depending on the prevailing economic situation. The probability of securing an apprenticeship increases when the candidate can demonstrate a low rate of absence and good grades from lower secondary school, is male, belongs to the ethnic majority, has a father with a vocational education and remains of age for upper secondary education (Markussen et al., 2011; Markussen et al., 2008; Markussen \& Sandberg, 2005). This ' $2+2$ ' model, which forces the student to change from one arena (school) to another (work placement) in the middle of their education, can in itself be said to pose an arbitrary structural challenge for the vocational student, over which the candidate has little control. For this reason, the student may achieve the best grades and meet all the school's requirements but still fail because employers can choose who they want to recruit to the apprenticeships they offer. This arbitrariness means that some are pushed out despite their best efforts, causing them to lose their lawful right to an upper secondary education if this coincides with the expiry of their allotted time of five years (Reegård \& Rogstad, 2016).

The general perception of what happens when young people drop out has changed (Dorn 1993); dropping out (and re-entering) is seen as an individual's decision, shaping their own fate (cf. MacDonald's (2011) critique of contemporary public labour policy). In its raw form, this individualisation thesis suggests that young people are now expected to think of themselves as creative, flexible and in charge of their own decisions in addressing life's challenges (Woodman \& Wyn, 2015, p. 46). They choose their education, their school and their career direction, and they fight their own battles to join the workforce. In this individualised world, young people are seen as entrepreneurs of their own lives. In Risk Society, Beck (1992) proposes that the young form their own lives through the decisions they make in relation to their education and subsequent career. In their reappraisal of Beck, Woodman and Wyn (2015) suggest that these formative decisions should be studied to clarify how institutional change translates into individual biographies. We call these decisions 'tightrope biographies', echoing the idea of 'choice biography' ascribed to Beck by critics of the individualisation thesis (cf. Woodman \& Wyn, 2015, p. 46). The choice biography supposedly captures the trajectory of young people in today's global knowledge society, where everybody is seen to form their own social biography through individual entrepreneurial spirit. Yet according to Woodman and Wyn, while the knowledge society has increased worldwide participation in education, 'In the global competition for jobs the apparent value of investing in knowledge building has largely failed to materialise. Instead, young people are faced with a highskill, low wage labour market" (2015, p. 31). Rather than emphasising "choice', Beck invoked the idea of 'tightrope biography' to describe how the young must navigate according to guidelines that compel them to think in terms of 'self organization' and 'self thematization' (Beck \& Beck-Gernsheim, 2002, p. 23).

The present study adopts a similar position in exploring young people's stories about their non-linear schooling careers. In a global world geared towards education, they have dropped out and re-entered a vocational system whose inherent arbitrariness they cannot overcome or fully control. In these circumstances, they are compelled to develop stories or biographies that frame their decisions as self-made choices. In so doing, they are like tightrope dancers, who must adapt to the rope they are given, finding their own way of 
dealing with 'institutional change that is translated into [their] individual biographies' (Woodman \& Wyn, 2015, p. 47). In trying to make sense of how study participants recounted their own stories, we have identified three such 'tightrope biographies' — or 'tightrope dances' as we now prefer to characterise them.

\section{Methods}

The research project underpinning this paper is a longitudinal qualitative study, in which selected young people are trailed through regular interviews. The collected data build on students' own stories and descriptions to elucidate their tightrope biographies. The core idea is to explore the dropout issue as a socially mediated phenomenon, accessing young people's accounts of how they arrived at the decision to return to school.

The interviews are conducted informally; discussion of the informants' current interests is developed through follow-ups, mirroring their stories. The method involves what Tanggaard (2013) called 'voice research', accumulating qualitative 'snapshots' (cf. Jonker, 2006) based in the young person's own vocabulary and emphasising where, when and how the interviews are conducted. Focusing on how vulnerable youth assign meaning to their life path over time yields a collection of narratives for interpretation. For instance, one observed tendency is that, in their relationship to education and training, these students are often seen as 'outsiders'. Becker (1963) claimed that young people labelled in this way are not kept 'outside' by their own decisions but by a society that marginalises anyone who infringes the rules for membership of that society. Dorn (1993) aligns with this view, arguing that the term 'dropout' is a label created by society rather than by those dropping out.

Exploring young people's own stories requires an indirect interviewing approach (Moshuus \& Eide, 2016). This is based on the ethnographic interview (Spradley, 1979), which attempts to engage the informant in a conversation in which both questions and answers should ideally extract the essence from the informant's context. Building the conversation on the informant's responses concerning hobbies and currents interests is an example of 'happenstance' (Moshuus \& Eide, 2016, p. 4ff), in which something unforeseen moves the research situation from an interchange between interviewer and informant to a more personal exchange. This approach ensures that students' stories about dropping out of school are less dictated by the researchers' own terminology, and each interview followed similar strategies. Ensuring that the research agenda is present only indirectly introduces a level of interpretative complexity that enriches guesswork around of our informants' intended meanings and perceptions of schooling and, perhaps more importantly, their ways of framing (Fine, 1991) their lack of schooling.

This ongoing longitudinal study is in its fourth year (of ten), and the present article draws on a selection of preliminary findings, based on completed interviews and accompanying field notes. The collected data include field notes, observations and transcribed interviews, which are assembled, stored and coded using the qualitative data analysis software NVivo. The young people recruited for the study were all at risk of dropping out or abandoning education, or had already had such an experience (Markussen, 2014). 
The project follows 71 young people in the county of Telemark, Norway, over a 10-year period from 2013 to 2023. Drawn from this original selection, 40 first year students in vocational upper secondary school are participants. The participants are following vocational strands that have particularly high dropout rate. The second part of the selection is recruited among young school leavers who are on welfare. All are aged between 16 and 21 years. Cooperation between the researchers in this project and the leaders of the welfare offices and schools resulted in the selection of the informants. Based on six of these students' stories, this paper describes the three tightrope dances, capturing differences and similarities in the process of returning to upper secondary school.

\section{The Tightrope Dancers}

In this study, we build on the data material collected from the first three years of the longitudinal study. The findings presented in this article are to be regarded as preliminary. The present patterns we see might be different as the study precede. When analysing the youths' stories, we found patterns of different stability in their relationships evolved over the years. One was of the youths' stable stories, where the relationships between the young people and their environment are described as robust and strong. Another was of more unstable stories, showing patterns of some relationships being wounded. The last pattern was of the damaged stories, of young people having several completely broken relationships. We call the three relationship positions for "the steady", "the shaky" and "the shivering".

The six stories referred to here were told by young people who have dropped out of school, received help over time from the welfare system and have re-entered vocational education. The stories describe their experiences of dropping out and their re-entry to vocational school. All of them had been on welfare for several months when we met for the first time at their local welfare office. They came from a low socio-economic background, with parents who themselves had a low level of education. By the time of the second interview, all had found their way back to school and were keen to succeed.

While their stories appear to share some similarities, a pattern arise where three different ways of understanding these young people as tightrope dancers can be understood as: "the steady", "the shaky" and "the shivering".

\subsection{The Steady}

Several participants' accounts of their re-entry to vocational education sounded like a positive story of completion. The stories of Kent and Noman are good examples of The Steady.

When we first met at the local welfare office, Kent was busy applying for jobs. He told us that getting a job was a temporary measure, and that in the autumn he would return to school. Originally, he was in the food and restaurant strand, training to become a chef. However, he said, 'after half a year, I noticed that this wasn't for me'. Nevertheless, he stayed on until he started his apprenticeship. 'I couldn't quit, because I had such good friends in the class. They held me back a little bit. [...] However, when I started 
as an apprentice and really felt what working would be like, I knew that "this won't work"'. So, although Kent knew quite early on that working as a chef was not for him, he stayed on, mostly because of his friends. When he finally faced reality, it was too late in the autumn to start anew. However, the experience of being an apprentice helped him to realise that he wanted to become a plumber, following an incident at his apprenticeship placement. He managed to unblock a drain, something no one else could do: 'I noticed that in this situation I could actually manage'. Kent felt he finally got a positive response from his colleagues, as he mastered the situation and was told he did an excellent job. This confirmed his sense of being in the wrong place and helped him to decide to drop out and to re-enter in a new strand.

Like Kent, Noman completed his two years of vocational training at school, majoring as a car mechanic in the technical and industrial production strand (TIP). Although a conscientious student, he did not get as far as becoming an apprentice. What stopped him, he said, was three days of absence when he went into hospital for an operation. Noman did not know the social code forbidding days out of school when applying for an apprenticeship. In fact, hospitalisation and post-operative convalescence should count as a legitimate absence, and should not appear on his certificate, but he may have been unaware that he needed to document this.

Noman and his parents are refugees from Asia, and his informal network of family and friends could not advise him on how to proceed to secure an apprenticeship. Noman was undeterred when he failed and decided to enter a different vocational strand straight away. However, just a week after term had started, he ran into difficulties when he was told it was too late. He felt that he was not treated like other students: 'There are a lot of others who get it [a place at school] after a month, so why didn't I get one after a week?' He found it unfair that others were able to return to school even though they had applied later.

By the time of our second meeting, Kent was starting the first of two years in the building and construction strand, and Noman had finally been readmitted to the second year in a different vocational strand, majoring in transport. Both reported that they were doing well at school and looking forward to their apprenticeship. Sponsored by the school, Noman was taking his licence for heavy vehicles. He had been in touch with a number of firms to seek an apprenticeship and was now waiting for a reply following an interview. Noman also sent his documents to another firm and was waiting to hear about a possible interview. When asked about the completed interview, he described it as follows.

He said that I had a grade 3 [ 6 being the best, 1 being fail], and that I have a 3 in everything, haven't I? Then he said; "You have to work a bit harder for the marks, don't you?" And he noted that I had four days absence. That's because we have these driving lessons and everything, so it's four days and seven hours. Then he said "Yes. I think the absence is a bit much". I said "It's the driving school and everything. And we are in the process of taking our driving licence as soon as possible".

Although he was told his grades were a bit low, and he was questioned about his absence, 
he felt the interview had gone well. He had made use of the school's sponsored courses to get a driving licence, and once again, the resulting absences for driving lessons (which should probably not have been recorded on his school sheet) led the potential employer to ask questions.

Kent reported that he loved his school. He could skip some of the subjects he had previously completed, and he said he was doing well in the other subjects. However, he was not going to be a plumber.

$\mathrm{K}:[\ldots]$ I have switched again. I am now going to be a concrete worker.

I: Ok.

$\mathrm{K}$ : So, the first year we did carpentry, so then I decided to become a carpenter. But then we came to the concrete workshop, and we were going to do formwork and bricklaying and things like that, and then I wanted to be a concrete worker.

I: Yes, exactly.

$\mathrm{K}$ : So it changes all the time. It is so strange.

Kent said that the teachers at school were good at motivating him. At the beginning of the year, when he had one teacher, he wanted to be a carpenter. However, his last teacher had motivated him to work with concrete, and Kent admitted that this had stuck in his mind because it happened at the end of the year. He had secured a placement (for work experience) with a big company working with concrete, and he was hoping for a summer job there. Kent knew through his network that the company had many new upcoming contracts, making it easier to get a job there.

Both Noman and Kent had their parents' support for whatever they decided to do. Through his family, Kent has a large local network that provides help and support, which is how he learned about the job openings in the concrete company. Noman's network has fewer ties to the local labour market. Both have a lot of close friends; while Kent's friends are from where he lives and where he grew up, Noman has friends within his country's network scattered all over Norway. That network also helps young people to find work opportunities, although outside the apprenticeship arrangement.

Students in this position can be said to perform a steady dance on the tightrope. These two young men, whose education has been stopped, both describe their dropout situation as a consequence of their own actions. Kent decided to drop out of his training because he no longer wanted to be a chef, and Noman failed to convince the employer to hire him. Yet according to Noman, the failure to convince the employer was not a failure but the unfortunate outcome of a close race, and next time, he would make it.

Similarly, both described their return to school as the result of decisions they had made. When Kent's superior at the restaurant applauded his way of unblocking a drain, it made him decide to become a plumber; then he changed his mind again, thanks to an inspiring teacher. However, as he recalls, it was his decision to become a concrete worker. Noman's negative experience with the interview and his initial problems with re-entry did not prevent him from returning to a new strand of vocational education. Both men believed they were making their own decisions, although both were surrounded by informal networks that were ready to step in, helping them to overcome every hurdle. 
Among tightrope dancers, they are The Steady, even if both may still be years from completing.

\subsection{The Shaky}

Some of the young people in our study appeared to do well on re-entering vocational education, but their stories suggested that they were struggling in other parts of their lives. While it might seem that all is well, a closer look at this group suggests that certain circumstances in their lives disrupt the balance and may affect their chances of reaching their goal of completion. We characterise these dancers on the tightrope as The Shaky.

Nils gave the impression of being quiet and shy when we first met at the local welfare office. He told us that he had failed to secure his first choice, which was electro, as he wanted to work with computers. Instead, he entered TIP and struggled a lot with learning and remembering the terminology. He completed the two years, but when he tried to get an apprenticeship, he found himself at a loss. 'No one wanted to take me in', he said. He experienced this rejection as something to do with him as a person rather than as a consequence of a lack of places.

After getting in touch with his local welfare office, Nils got a work experience placement at a local business. However, when he had completed the placement, they did not offer him a job or even a summer job. He wanted to learn something different, starting school again in the media and communication strand.

Lina came across as a vibrant and strong girl at our first meeting. She told us that she had thought a lot about her situation and now wanted to take charge of her life by returning to finish her schooling in the health and social strand. She felt she had wasted a lot of time.

I threw away [my time at] upper secondary school. I have thrown away a lot of my life that I could have used to do some good. I mean, I have such huge potential, haven't I? When I really tried in tests and so on, I got fives and things like that. So, in a way, I could have done a lot better if only I didn't have everything else to think about. And now it is just me, so now I want to...

Lina had almost completed her schooling, and could have continued, if she had taken some exams. She told us that she did not take her exam because her dog had died. However, from what she told us, it soon became clear that there was a lot more to her decision than her dog dying.

Lina spoke about her difficult childhood, as both her parents were drug addicts. Although her mother found a more stable husband when Lina was very young, she started using drugs again when they split up. Lina talks about how she moved a lot, changing schools, and how Lina lied to the childcare officers to get them off her case. Because her mother was unstable, it became Lina's job to take care of her, and of her younger brother. 
When we met Lina again, she was back at school, taking the subjects she had missed and getting good grades. She was now living with her grandparents, who kept a close eye on her and told her she was welcome to live there if she stayed in school, which to a certain extent she did. She also told us that she was very happy at school and enjoyed her class. We asked her if this would help her to complete:

L: Yes, a lot. I feel more like being at school, and I have had these problems with absence and that, because I don't thrive, do I? [It is] difficult for me to stay there because of anxiety and that, but it is a very good class, so.

I: Yes, so you are not away a lot, then?

L: Well, I have some absences.

I: It was you who sort of implied this, wasn't it? [Saying] "Yes, I like being at school".

L: Yes, I switch, because I sort of... I notice how the school year is going; at the beginning of the year I am very motivated not to come in too late and so on, and then it dwindles away, doesn't it? Today was like that; I was in bed at half past seven [school starts at eight] and just sort of... "Shall I be bothered to go or not?" Suddenly, I lose all my energy.

It seemed as if Lina was not completely out of the woods. She still struggled with absence. She said she was fortunate to have a teacher who pushed her to come to school and understood her problems. Lina had a lot going for her; her grandparents supported her and demanded that she puts her efforts into her schooling. Her mother moved far away, making it easier for Lina to ignore her needs and focus on herself. Her stepfather is a stable element in her life, she has many friends and several of her friends' relatives are there to help her. In other words, she has a network that actively supports her.

Nils' situation is a little different. When we met him for a second time, he was living away from his home town, in a bedsit. His family was scattered, his parents had recently divorced, and his mother had moved away with his brother. His father was still living in Nils' home town, although at a distance from him. He had no informal network, did not go out, and had few friends. He lived on a student loan and did not have a part-time job but lived on a very meagre budget. However, he had started the new school and was beginning afresh, making progress and managing quite well academically.

Young people in this position (The Shaky) have a lot going for them when returning to school, but there are challenges that sometimes rattle them. Although they have a history of struggling, they are motivated to complete what they have now started. They have found their place. It was clear that both Lina and Nils were satisfied with their choices-Lina in continuing where she left off, and Nils trying something new that he enjoys. Young people in this position manage quite well at school and tend to have a network of friends and/or family that supports them. However, there is something lingering, something still not quite there, that may interfere with their schooling, though it may be unrelated to their educational skills. Lina and Nils both achieved good grades but face certain challenges that disturb the balance, putting them on shaky ground, and these challenges must be dealt with. For Lina, this manifests in her continuing absences from school, making her anxious about being unable to shake off old self-destructive 
behaviour. For Nils, it is his sense of being alone in the world; his family is not there for him, either physically or psychologically, and while he feels part of an informal student collective at school, he has never managed to establish any social contact with any of them outside school.

\subsection{The Shivering}

In this position of The Shivering, the two storytellers were back in school but seemed to be struggling. The characteristics of the shivering position may be understood as more unstable than the shaky. These young people seem to encounter more challenges and have broken relationships with their environment. Their stories led us to question whether they would manage to complete, or if the challenges and instability issues would cause them to give in and so fall off the tightrope. Lars and Karen were both forthcoming when interviewed, but they were less descriptive in their narratives than the other four. Karen's interviewer commented on her difficulties in understanding words and expressions and the need to use simple vocabulary.

Lars told us he was forced to drop out because he was accused of abusing hashish. However, he insisted that this was only partly true. He admitted that he was using, and that he knew that he would have to take a urine sample at some stage because of the school's suspicions. In that sense, he was not forced to quit, as he saw it coming and still did nothing to avoid the confrontation. He knew he had not passed in all his subjects, and being forced to take the urine sample would not change anything. He knew he would not have been able to continue; he felt he was doomed to fail, no matter what he did. Lars started using hashish at fourteen, and it has dominated his life ever since. He said he was curious; he wanted to try it, and by the time he was fifteen, he was using all the time. He said he regretted this because there had been lot of bother, always being suspected of being a drug abuser. It seemed as if he did not regret using, but that he regretted all the commotion around his use being labelled as 'abuse' or 'addiction'. We were not surprised, then, when he told us he was using hashish when we met (after he had returned to school).

Lars lets us know that his father was not pleased about his consumption, so he no longer went home high. He said that he only smoked ' [...] during the night, my father has a super nose for hashish. [...] He has threatened to throw me out if I continue, and then I have to pay back what they have paid for me to get my driving licence'. His father would drag him out of bed and drive him to school to get him there in time. Evidently, he still wanted to use hashish, but his father's strong will kept him attending school. However, his habit was causing him to struggle with paranoia and anxiety. We asked how that affected him.

No, there was a period of a couple of months when I felt constantly monitored. If I was out, I felt like someone was following me. And, when I was at home, I felt there were cameras all around and microphones and things like that. So, it wasn't much fun. [...] Yes, so I struggled a little bit with this, and also meeting new people... but it's getting a little bit better now [...] I 
just have to sit in class and find a place to sit where there aren't a lot of other people. I can't sit in the canteen because there are so many people and things there. So I just have to sit on a bench or some chairs where there aren't that many around. [...] I can't be alone either when there are so many people around me, then I just have to go home.

Lars told us how this affected his schooling, but he did not confide in anyone at school and would not explain his increasing absences from class to them. This may be because he was caught using hashish once before, and so if he told anyone at school about his situation, they would test him again. This was his predicament. He could not make up his mind how to balance his hashish use with his efforts at school. The possibility of being caught and the influence on his life, leading to absences, all added up to the possibility of failing to complete.

Karen's story told of her struggle with bullying from first grade at primary school throughout lower secondary school. In lower secondary school, she went to a psychologist, and she was sometimes ill during these three years and unable to attend school. She also told us that she was on medication for ADHD. Karen's life seemed to involve regular dramatic incidents, as when a friend ended up in a coma following an accident, or when she ran away from the police after becoming involved in a difficult situation. She told us about anxiety and bullying on entering vocational school.

K: And I was very motivated, I had thought about and, for example, yes, to get to know a lot [of other students]. But because I was now at school to learn, to take an education, I didn't want to [make bad choices]. If I got to know someone, perhaps they were the wrong kind of people. So, I kept mostly to myself, but then I sort of got a type of anxiety.

I: Ok?

K: Because I didn't know anyone, and every time I went to the canteen, I got the evil eye [from the other students], and they didn't know me, and they whispered and looked at me in that way.

The first time around, Karen had managed to last until the beginning of the second year; then she left because she felt unhappy there. She described how the others looked at her, and how it made her feel uncomfortable and insecure.

She decided to try again when a woman from the county council phoned her. Her decision was influenced by seeing how her stepsister struggled. 'She can hardly pay her rent, [...] and I realised that I don't want to end up like that'. While proud of what she had achieved so far, she also admitted to some absences but believed she would manage to get into the second year. Again, she was struggling a lot, making it difficult to attend school, and her stepfather was sick.

So, it is a lot like, well, it affects school sometimes that one isn't, well... I have some absences and that's because of, yes, my stepfather has cancer. And I have had this winter depression and this anxiety and so on, which has taken a lot of energy out of me. 
Karen said that the teachers supported her; when she was absent, they told her they had missed her. She also said that her marks were generally good while admitting that her grades in Maths and Science were not so good. Now twenty, this was the first time since eighth grade that she had actually achieved good grades. She believed this had something to do with the fact that she had been working for a while - first at her stepfather's and then in a local shop. Now, at the end of the year, she was a little insecure about one subject (Mathematics), and if she failed, that would stop her progression.

Students in this position do a shivering dance on the tightrope. The Shivering's stories typically express anxiety, loneliness and a limited supporting network. Most importantly, both Lars and Karen found that they must cope with the impact of external factors in order to continue their schooling. In these stories, the issues are drug use and bullying. Both students have returned to school, but they continue to struggle, both at school and at home. Their re-entry can hardly be described as their decision alone. Lars' father invests a lot of energy in getting his son to stay in school, and Karen returned after being followed up by the local authorities. Lars will not change his ways, and Karen is dealing with her stepfather's illness, as well as spending time with her friends away from school. Given these challenges and instability, will they complete, or will they fall off the tight rope?

\section{Defining the Dancer's Dance: Concluding Remarks}

The aim of this paper was to trace how students make their way back to school by asking what are their stories of dropping out and re-entry? In particular, we wanted to identify the key elements in the making the decision to return to school after dropping out. The present findings are based on a preliminary analysis of the students' individual stories. Our argument is inspired by Woodman and Wyn (2015), which turns the individualisation thesis upside down. Applying their interpretation to the six students' stories, we have elucidated the different processes by which these three categories of tightrope dancers got back on track to re-enter vocational school.

As we can all imagine, dancing on a tightrope is difficult. It requires training and repeated rehearsal. These young people told us about their differing non-linear paths back to school, narrating their repeated attempts to get their education on the right track in ways that warrant comparison with dancing on a tightrope. As their stories show, they face different challenges. Like tightrope walking or dancing, it seems to be more difficult for some than for others to find their balance. The three tightrope dances inherent in their re-entry stories show how different constraints, far beyond the youth's own choices and decisions, appear to them as their own particular dance. This highlights the importance of moving on from the initial discovery of the particular dancer to the work of defining the dancer's dance. Based on these early findings, we can identify three types of dancer: The Steady (who are managing well and getting closer to their target; The Shaky (who are also progressing but face some challenges, mostly outside of school, that make the rope harder to cross); and The Shivering (who fumble and are in danger of falling off in their efforts to complete). For this third group, their challenges are so 
complex or immense that they may find it difficult to move far enough to cross the rope.

In line with the individualisation thesis, Kent and Noman provided clear examples of young people who act as entrepreneurs in their own lives. However, a closer look reveals that their high motivation to stay on track reflects more than their own decisions, as both perceived that others have supported their efforts. Most importantly, their surrounding informal networks supported almost every decision they made, helping them to overcome every hurdle. For Lina and Nils their work at school offered hope of completion, but their efforts may yet be interrupted by issues external to their school career that continue to impact their educational efforts. Lars and Karen's re-entry can hardly be seen as resulting from their decisions alone, even if they present it in that way. Both must continue to cope with the impact of external factors that have severe negative effects on their schooling, leading us to question whether they will complete, or whether these challenges and instability will cause them to give up again.

All of these young people chose to characterise their schooling as the result of selfmade decisions. Even Lars, who was thrown out of school, said that he let it happen; he knew it was coming, if not for this reason then for something else, and it was his own choice to leave. Only Nils said he was helpless because no one wanted him, prompting the question, is Nils aware of his situation in a way that differs from the others? Caught up in the individualisation thesis, do the others navigate and ignore the institutional pressure that forces their hand? Nils seemed to realise that the situation was not to his advantage, but rather than blaming systemic issues beyond his control, he seems to blame himself by insisting that it was him they rejected.

Both internationally and nationally, there is extensive research on young people in the risk zone. We know a great deal about youth at risk and school leavers. However, even though we have a nuanced picture of how risk factors are distributed among young people, our research show that within the same risk groups there are major differences between how youth master different challenges in carrying out their educational and potential apprenticeships prospects. There are young people who perform well while others struggle, some, as we have presented, to a considerable extent.

In this article, we have complemented the view of youth at risk with a perspective of socially mediated relationships. When studying young people in the same risk group, we find what so far resembles a systematic difference in the interaction of relationships with their surroundings. The descriptions of their relationships reflect our research method, which emphasizes the young people's own stories about their experiences.

What can we learn from these stories? The tightrope analogy foregrounds the importance of the developing relationship between the individual student and the vocational training system. The analogy also allows us to shift the focus from the student's own choice to their effort to find their balance in a 'state of permanent (partly overt, partly concealed) endangerment' (Beck \& Beck-Gernsheim, 1996, p. 25). Although these young people present themselves as makers of their own stories, we see them struggling to find their balance in situations that are not of their making. In a forthcoming paper (Bunting \& Moshuus, 2017a), we note the importance of the large research literature (cf. De Witte et al., 2013, Rumberger, 2011) reporting the large number of 'individual factors' and 'institutional factors' at play when young people abandon their schooling. 
At the same time, we need to know more about the often complex interactional processes that influence dropping out of school (cf. Brown \& Rodriguez, 2009). The stories presented here suggest that these processes are equally important in determining how young people re-enter education. The three positions described here highlight the differing experiences of those returning to school. The first of these (The Steady) refers to students who are motivated, plan for their future, their relationships are robust; they have friends and networks as well as supportive and interested parents, and have no external problems that disturb their schooling. Those in the second position (The Shaky) are also motivated but have a history of struggling privately; their relationships seem to be damaged which is likely to influence their schooling to some extent and represent a latent risk factor. The third position (The Shivering) includes young people who need help to get back on track. Their motivation for staying at school is the desire for a good life, which they might otherwise miss, but they remain unsure how to get there. They struggle with life issues, their relationships are broken both at school and privately, this is likely to affect their schooling and their prospects of completing.

In another paper (Bunting \& Moshuus, 2017b), we elaborate on the perspective of Michelle Fine (1991) to explore the importance of young people's interactions outside school in understanding why some end up completely disengaged from school. Here again, it becomes clear how re-entering school demands quite distinct balancing acts, depending on the student's circumstances outside school. 


\section{References}

Baker, D. P. (2014). The schooled society: The educational transformation of global culture. Stanford, CA: Stanford University Press.

Beck, U. (1992). Risk society: Towards a new modernity. New Delhi: Sage.

Beck, U., \& Beck-Gernsheim, E. (1996). Individualization and "precarious freedoms": Perspectives and controversies of a subject-orientated sociology. In P. Heelas, S. Lash, \& P. Morris (Eds.), Detraditionalization: Critical reflections on authority and identity (pp. 23-48). Oxford: Blackwell.

Beck, U., \& Beck-Gernsheim, E. (2002). Individualization: Institutionalized individualism and its social and political consequences. London: Sage.

Becker, H. S. (1963). Outsiders. Studies in the sociology of deviance. New York, NY: The Free Press of Glencoe.

Brown, T. M., \& Rodriguez, L. F. (2009). School and the co-construction of dropout. International Journal of Qualitative Studies in Education, 22(2), 221-242.

Bunting, M. \& Moshuus, H. G. (2017a). Young peoples' own stories about dropping out in Norway: An indirect qualitative approach. Acta Didactica Norge. Vol. 11, Nr. 2, Art. 3. retrived from: https://www.journals.uio.no/index.php/ad no/article/view/3182/4763

Bunting, M., \& Moshuus, G. H. (2017b). Framing narratives-Youth and schooling, silencing and dissent, Studia Paedagogica, 21(4), 35-52. Retrieved from: http://www.phil.muni.cz/journals/index.php/studia-paedagogica/article/view/1569

De Witte, K., Cabus, S., Thyssen, G., Groot, W., \& Maassen van den Brink, H. (2013). A critical review of the literature on school dropout. Educational Research Review, $10,13-28$.

Dorn, S. (1993). Origins of the 'drop-out problem'. History of Education Quarterly, $33(3), 353-373$.

Falch, T., \& Nyhus, O. H. (2011). Betydningen av fullført videregående opplæ ring for sysselsetting og inaktivitet blant unge voksne, Søkelys på arbeidslivet, 28(4), 285299.

Fine, M. (1991). Framing dropouts. Notes on the politics of an urban public high school. Albany, NY: State University of New York Press.

Guest, R. (2016). Generation Uphill. The Economist. Retrieved from: http://www.eco nomist.com/news/special-report/21688591-millennials-are-brainiest-best-educa tedgeneration-ever-yet-their-elders-often

Hiim, H. (2017). Ensuring Curriculum Relevance in Vocational Education and Training: Epistemological Perspectives in a Curriculum Research Project. International Journal for Research in Vocational Education and Training, 4(1), 1-19.

Høst, H. (ed.) (2008). Fag- og yrkesopplæringen i Norge- noen sentrale utviklingstrekk. Rapport 20. Oslo: NIFUSTEP.

Jonker, E. F. (2006). School hurts: Refrains of hurt and hopelessness in stories about dropping out at a vocational school for care work. Journal of Education and Work, $19(2), 121-140$. 
MacDonald, R. (2011) Youth transitions, unemployment and underemployment. Plus ça change, plus c'est la même chose? Journal of Sociology, 47(4), 427-444.

Markussen, E. (2014). Utdanning lønner seg. Rapport 1. Oslo: NIFU.

Markussen, E., \& Sandberg, N. (2005). Stayere, sluttere og returnerte: Om 9756 ungdommer pa Østlandet og deres karriere $i$ videregående opplaring frem til midten av det tredje skoleåret. (186). Nordisk institutt for studier av innovasjon, forskning og utdanning. Oslo: NIFU

Markussen, E.; Frøseth, M. W.; Sandberg, N., Lødding, B., \& Borgen, S. (2011). Early leaving, non-completion and completion in upper secondary education in Norway. In S. Lamb, E. Markussen, R. Teese, N. Sandberg, \& J. Polesel (Eds.), School dropout and completion. International comparative studies in theory and policy (pp. 253-272). London: Springer.

Markussen, E., Frøseth, M. W., \& Sandberg, N. (2011). Reaching for the unreachable: Identifying factors predicting early school leaving and non-completion in Norwegian upper secondary education. Scandinavian Journal of Educational Research, 55(3), $225-253$.

Moshuus, G. A., \& Eide, K. (2016). The indirect approach: How to discover context when studying marginal youth. International Journal of Qualitative Methods, 15(1), $1-10$.

Reegård, K., \& Rogstad, J. (Eds.) (2016). De frafalne: om frafall i videregående opplaring. Oslo: Gyldendal Akademisk.

Rumberger, R. W. (2011). Dropping out. Why students drop out of high school and what can be done about it. London: Harvard University Press.

Spradley, J. P. (1979). The ethnographic interview. Fort Worth, TX: Harcourt.

Statistisk Sentralbyrå. (2016). Gjennomstrømning i videregående skole. 2010-2015. Retrieved from: http://www.ssb.no/utdanning/statistikker/vgogjen/aar/2016-0602

Tanggaard, L. (2013). An exploration of students' own explanations about dropout in vocational education in a Danish context, Journal of Vocational Education 8 Training, 65(3), 422-439.

Utdanningsdirektoratet. (2015). Gjennomføringsbarometeret 2015. Retrieved 22.01.2017 from http://www.udir.no/globalassets/filer/tall-ogforskning/statistikk/gjennomfor ing/gjennomforingsbarometeret-2015.pdf

Woodman, D., \& Wyn, J. (2015). Youth and generation: Rethinking change and inequality in the lives of young people. London: Sage. 


\section{Bibliographical Notes}

Dr Mette Bunting is Professor of Educational Science in the Department of Educational Science at the University College of Southeast Norway. With Geir H. Moshuus, she leads the research project Youth, Completion and Dropout in Telemark. Her interests are youth and dropout, learning strategies, leadership and inclusive education.

Dr Torill Aagot Halvorsen is Associate Professor of Educational Science at the University College of Southeast Norway. She is part of the research project Youth, Completion and Dropout in Telemark. Her interests include youth and institutional pushout mechanisms and comparative research on language and literacy in educational systems.

Dr Geir H Moshuus is Associate Professor of Social Anthropology at the University College of Southeast Norway. With Mette Bunting, he leads the research project Youth, Completion and Dropout in Telemark. His current interests are youth research, marginality, drug consumption and subculture in modern society.

\section{Acknowledgement}

The article is the result of equal contributions by the three authors. 